\title{
Governance by conditionality: EU rule transfer to the candidate countries of Central and Eastern Europe
}

\author{
Frank Schimmelfennig and Ulrich Sedelmeier
}

\begin{abstract}
In the process of the EU's eastern enlargement, the Central and Eastern European countries (CEECs) have undergone a major process of external governance. What are the main characteristics of the mode of EU external governance in this region, and under which conditions is it most effective for the transfer of EU rules to the CEECs? The article presents the findings of a collaborative international research project including comparative case studies of EU rule transfer in a great variety of policy areas and CEECs. They show that rule transfer is best explained by an external incentives model of governance; its effectiveness varies with the credibility of EU conditionality and the domestic costs of rule adoption. The impact of these conditions, however, depends on two contexts of conditionality: democratic conditionality and acquis conditionality.
\end{abstract}

KEY WORDS Central and Eastern European countries; conditionality; enlargement; European Union; Europeanization; external governance.

\section{INTRODUCTION $^{1}$}

The 'governance approach' to the study of the European Union (EU) is usually applied to describe and analyse particular forms of policy-making within the

(1) EU (see e.g. Jachtenfuchs 2000; Kohler-Koch and Eising 1999). However, it is also relevant in the EU's external relations (cf. Friis and Murphy 1999). In the process of eastern enlargement, the Central and Eastern European countries (CEECs) have undergone a major process of external governance. The desire of most CEECs to join the EU, combined with the high volume and intrusiveness of the rules attached to its membership, have allowed the EU an unprecedented influence on the restructuring of domestic institutions and the entire range of public policies in these countries. A key difference between the internal and the external dimension of governance is that while the former concerns primarily the creation of rules as well as their implementation in national political systems, the external dimension is exclusively about the transfer of given EU rules and their adoption by non-member states.

We can distinguish two different aspects of the external dimension of EU

Journal of European Public Policy

ISSN 1350-1763 print; 1466-4429 online (C) 2004 Taylor \& Francis Ltd

http://www.tandf.co.uk/journals

DOI: $10.1080 / 1350176042000248089$ 


\section{Journal of European Public Policy}

governance. The first concerns the export of EU systems of governance as such, and specifically of a particular mode of 'network governance' (see, e.g., Kohler-Koch and Eising 1999; Peters 2000) that the literature identifies as characteristic of the EU. Here the focus is on what is exported, i.e. the substance of governance modes, and to what extent these affect policy-making processes and relations between actors in external states. The second aspect of EU external governance concerns the governance mode through which the EU transfers given rules. The key question is how rule transfer happens, i.e. which form it takes. In this article, we focus on this latter aspect of EU external governance. Accordingly, the key questions are the following: what are the main characteristics of the mode of EU rule transfer to the CEECs and which governance mode is most effective for rule transfer?

EU policy towards the CEECs is generally described as predominantly a policy of conditionality. However, the mere use of conditionality by the EU does not necessarily tell us much about the underlying mode of governance and the conditions under which EU rules are transferred to the CEECs. EU conditionality might be encompassing, but it might not be effective in achieving rule transfer in certain issue-areas or countries. Furthermore, there is not necessarily a causal link between the presence of EU conditionality and successful rule transfer in particular issue-areas. Thus, we need to distinguish analytically between the use of 'conditionality' as a political strategy and its causal impact on domestic politics.

The dominant logic underpinning EU conditionality is a bargaining strategy of reinforcement by reward, under which the EU provides external incentives for a target government to comply with its conditions. However, these dominant features of conditionality might be superseded by other mechanisms that can also lead to rule transfer. First, in the process of systemic political and economic transformation that the CEECs are undergoing, they might consider EU rules as effective solutions to domestic policy challenges and thus adopt these rules independently of EU conditionality and their desire to join. Second, while the EU might provide incentives for the adoption of its rules, the mechanism through which the CEECs adopt these rules might relate to processes of persuasion and learning in which EU actors socialize CEEC actors rather than coerce them.

In this article, we outline a theoretical framework to study governance modes that lead to an effective transfer of EU rules to outside states and present the findings of a comparative analysis. We define the dependent variable of the analysis as 'rule transfer'. By analysing rule transfer, we focus on the adoption of EU rules in non-member states, i.e. their institutionalization at the domestic level. Such institutionalization includes the transposition of EU legislation into domestic law, the restructuring of domestic institutions according to EU rules, or the change of domestic political practices according to EU standards. We then specify an explanatory model of EU governance in the CEECs that underpins EU conditionality - the external incentives model as well as two alternative models. These models are not necessarily mutually 
exclusive; they may be partly competing, partly complementary explanations. But we can ask whether there is a dominant model that explains effective rule transfer from the EU to the CEECs. In order to assess the conditions for effective rule transfer, we draw on the findings of a collaborative research project on EU rule adoption in different policy areas and different CEECs (Schimmelfennig and Sedelmeier, forthcoming).

The main finding of the project is that rule transfer from the EU to the CEECs and the variation in its effectiveness are best explained according to the external incentives model and in particular with the credibility of EU conditionality and the domestic costs of rule adoption. The impact of these conditions, however, varies according to the context of conditionality. In the context of democratic conditionality, domestic adoption costs severely limited the effectiveness of EU conditionality - even when it was credible and rewards were sizeable. Authoritarian governments turned down the offer of membership rather than accept the political power costs of adopting liberal democratic rules. By contrast, in the context of acquis conditionality, variation in the size of domestic adoption costs only accounted for the speed of rule transfer but did not matter systematically for its effectiveness. We conclude the article by pointing out some problems and questions relating to future rule adoption and implementation in the CEECs once they are members and the mode of external incentives is no longer available.

\section{THREE MODELS OF EU EXTERNAL GOVERNANCE}

\section{The external incentives model}

In this section, we outline our explanatory model of EU external governance in the CEECs - the external incentives model - and briefly contrast it with two alternative models, the social learning model and the lesson-drawing model.

The external incentives model is a rationalist bargaining model. The actors involved are assumed to be strategic utility-maximizers interested in the maximization of their own power and welfare. In a bargaining process, they exchange information, threats and promises; its outcome depends on their relative bargaining power. ${ }^{2}$ According to the external incentives model, EU external governance mainly follows a strategy of conditionality in which the EU sets its rules as conditions that the CEECs have to fulfil in order to receive EU rewards. These rewards consist of assistance and institutional ties ranging from trade and co-operation agreements via association agreements to full membership.

EU conditionality mainly follows a strategy of reinforcement by reward (Schimmelfennig et al. 2003: 496-7). Under this strategy, the EU pays the reward if the target government complies with the conditions and withholds the reward if it fails to comply. It does not, however, intervene either coercively or supportively to change the cost-benefit assessment and subsequent behaviour 


\section{Journal of European Public Policy}

of the target government by inflicting extra costs ('reinforcement by punishment') or offering extra benefits ('reinforcement by support').

The analytical starting point of the bargaining process is a domestic status quo, which differs to some extent from an EU rule. This status quo is conceived as a 'domestic equilibrium' reflecting the current distribution of preferences and bargaining power in domestic society. EU conditionality upsets this domestic equilibrium by introducing (additional) incentives for compliance with EU rules into the game. Conditionality can affect the target government either directly through intergovernmental bargaining or indirectly through the differential empowerment of domestic actors. In the latter case, conditionality changes the domestic opportunity structure in favour of domestic actors with independent incentives to adopt EU rules and strengthens their bargaining power vis-à-vis their opponents in society and government (cf. Börzel and Risse 2000: 6-7; Knill and Lehmkuhl 1999: 6-8). In the end, however, rule adoption requires the authoritative decision of the target government, which seeks to balance EU, domestic, and other international pressures in order to maximize its own political benefits. The most general proposition of the external incentives model under a strategy of reinforcement by reward is therefore that a state adopts EU rules if the benefits of EU rewards exceed the domestic adoption costs. In turn, this cost-benefit balance depends on (i) the determinacy of conditions, (ii) the size and speed of rewards, (iii) the credibility of threats and promises, and (iv) the size of adoption costs. From these factors, we can derive hypotheses about the effectiveness of rule transfer in this mode of external governance.

\section{Determinacy of conditions}

Generally, the external incentives model suggests that - given a domestic equilibrium in the non-member country - EU rules will not be adopted if the EU does not set them up as conditions for rewards. In addition, the determinacy of the EU's conditionality and the determinacy of the rules from which it is derived enhance the likelihood of rule adoption. Determinacy refers both to the clarity and formality of a rule. The clearer the behavioural implications of a rule, and the more 'legalized' its status, the higher its determinacy. ${ }^{3}$ First, determinacy has an informational value. It helps the target governments to know exactly what they have to do to get the rewards. Second, determinacy enhances the credibility of conditionality. It is a signal to the target countries that they cannot avoid adopting an EU rule by manipulating the interpretation of what constitutes compliance to their advantage. At the same time, however, it binds the EU. If a condition is determinate, it becomes more difficult for the EU to claim unjustly that it has not been fulfilled and to withhold the reward. On the basis of these considerations, we formulate a determinacy hypothesis: ${ }^{4}$ the effectiveness of rule transfer increases if rules are set as conditions for rewards and the more determinate they are. 


\section{Size and speed of rewards}

Another source of variation under a strategy of reinforcement by reward is the size and speed of the conditional rewards. Accordingly, the promise of enlargement should be more powerful than the promise of association or assistance, and the impact of the EU on candidates for membership should be stronger than on outside states not considered potential EU members (cf., e.g., Smith 2001: 37-8). Moreover, the longer the temporal distance to the payment of rewards, the lower the incentive to comply (swiftly). Conversely, rule adoption becomes more likely the closer the day of EU enlargement decisionmaking gets. The corresponding rewards hypothesis is: the effectiveness of rule transfer increases with the size and speed of rewards.

\section{Credibility of conditionality}

A third set of factors has to do with the credibility of the EU's threat to withhold rewards in case of non-compliance and, conversely, its promise to deliver the reward in case of rule adoption. In other words, given a strategy of reinforcement by reward, effective external governance requires: first, the superior bargaining power of the external agency (otherwise threats would not be credible); second, on the part of the target states, certainty about the conditional payments (otherwise promises would not be credible). A discussion of credibility therefore has to address the conditions under which bargaining power and certainty are enhanced or impaired.

The first issue is capabilities and costs of the agency employing conditionality. On the one hand, the EU must be able to withhold the rewards at no or low costs to itself, and it has to be less interested in giving the reward than the target government is in getting it. In general, this condition is present in EUCEEC relations. Interdependence is highly asymmetrical in favour of the EU. Whereas the CEECs are only of marginal importance to the EU economy, the CEECs are heavily dependent on the EU market and will benefit much more strongly from accession than the EU member states (Baldwin et al. 1997; Moravcsik and Vachudova 2003: 46-52). On the other hand, however, the EU must be capable of paying the rewards (at a low cost to itself). Promises are not credible if they go beyond capabilities. The higher the costs of the rewards to the EU are, the more doubtful their eventual payment to the target countries will be. On the basis of this reasoning, assistance and association have been more credible rewards than accession. Eastern enlargement involves substantial costs to the organization, which - although far from being prohibitive - are likely to exceed the marginal benefits of the member states (Schimmelfennig 2003: 52-62).

However, one has also to take into account the 'sunk costs' of rewarding. In contrast to assistance, which requires comparatively small investments on the part of the EU and can be stopped rather easily, enlargement involves costly, long-term negotiations and preparations and a restructuring of EU institutions 


\section{Journal of European Public Policy}

and policies. The more the pre-accession process advances, the higher are the costs of withholding the reward, that is, the investments that would be lost if the process was broken off or postponed to sanction a candidate state. Therefore, the credibility of promises in enlargement conditionality increases over time as the credibility of threats decreases. Moreover, the opening of accession negotiations with, and the subsequent accession of, a first group of candidate countries increased the credibility of rewards for the remaining candidates, as it demonstrated that the EU was serious about enlargement.

Second, credibility depends on the consistency of an organization's allocation of rewards. If the EU were perceived to subordinate conditionality to other political, strategic, or economic considerations, the target state might either hope to receive the benefits without fulfilling the conditions or conclude that it will not receive the rewards at any rate. In both cases, the target state will fail to adopt EU rules. Another source of inconsistency would be internal EU conflict about conditionality. If target states learned about such internal conflict and receive inconsistent signals, they would be tempted to manipulate it to their advantage or simply be confused.

Third, cross-conditionality must be absent or minor. EU conditionality would not be effective if the target government had other sources offering comparable benefits at lower adjustment costs (Kahler 1992: 104, 111; Killick 1996: 221, 224). Yet, given their strong dependency on the EU market and the strong incentives of potential transfers from the EU budget and participation in EU decision-making, for most of the CEECs, there is no credible alternative to $\mathrm{EU}$ integration. In sum, we formulate a general credibility hypothesis: the likelihood of rule adoption increases with the credibility of conditional threats and promises.

\section{Veto players and adoption costs}

If non-member states are confronted with determinate and credible conditionality, and if they are offered equally beneficial rewards, the external incentives model postulates that the size of domestic adoption costs and their distribution among domestic actors determine whether they will accept or reject the conditions. We assume that adoption is always costly - otherwise it would have taken place in the absence of conditionality. Adoption costs can have various sources: first, they may take the form of opportunity costs of forgoing alternative rewards offered by adopting rules other than EU rules; second, they may produce welfare or power costs for private and public actors. On the other hand, adoption costs are balanced by the benefits of EU rewards. As a result, adoption costs may become negative: they turn into net benefits for some or all domestic actors. Given that EU rules have to be adopted and implemented by the government, the effectiveness of conditionality, then, depends on the preferences of the government and those of other 'veto players', that is, 'actors whose agreement is necessary for a change in the status quo'. According to veto players theory, 'the difficulty for a significant change of the 
status quo ... increases in general with the number of veto players and with their distances' (Tsebelis 2002: 37). ${ }^{5}$ For the purpose of this study, we reformulate this condition as the number of veto players with significant net costs of rule adoption.

Generally, the number of veto players is considered to be small in the CEECs (see, e.g., Dimitrova 2002: 176; Schimmelfennig et al. 2003: 498-9), but it may still vary in causally relevant ways across issue-areas (see, e.g., Jacoby and Cernoch 2002: 320). The scarcity of veto players increases the influence of the government as the main target of EU conditionality and the causal relevance of its cost-benefit assessment. Thus, we formulate the following adoption cost hypothesis: the likelihood of rule adoption decreases with the number of veto players incurring net adoption costs (opportunity costs, welfare and power losses) from compliance.

The external incentives model specifies conditions under which EU external governance is likely to produce rule adoption in the CEEC candidates for EU membership. On the one hand, however, there may be other conditions of effective governance omitted in a bargaining model of EU influence. On the other hand, the adoption of EU rules may not have been the product of proactive EU promotion at all but induced by domestic factors. On the basis of these considerations, we formulate two alternative models of external governance, the social learning model and the lesson-drawing model.

Two alternative models of external governance: social learning and lessondrawing

\section{The social learning model}

The social learning model follows core tenets of social constructivism. It has informed studies of international socialization in general (Checkel 2001) and constitutes the most prominent alternative to rationalist explanations of conditionality (Checkel 2000; Kahler 1992) and Europeanization (Börzel and Risse 2000). In contrast to the rationalist model of conditionality, the social learning model assumes a logic of appropriateness (March and Olsen 1989: $160-1)$. According to this logic, the actors involved are motivated by internalized identities, values, and norms. Among alternative courses of action, they choose the (most) appropriate or legitimate one. Correspondingly, arguing about the legitimacy of rules and the appropriateness of behaviour (rather than bargaining about conditions and rewards), persuasion (rather than coercion), and 'complex' learning (rather than behavioural adaptation) characterizes the process of rule transfer and rule adoption.

In this perspective, the EU is the formal organization of a European international community defined by a specific collective identity and a specific set of common values and norms. Whether a non-member state adopts EU rules depends on the degree to which it regards EU rules and its demands for rule adoption as appropriate in light of these collective identity, values, and 
norms (Schimmelfennig 2003: 83-90). The most general proposition of the social learning model therefore is: a state adopts EU rules if it is persuaded of the appropriateness of EU rules.

Several groups of factors impinge upon the persuasive power of the EU: legitimacy, identity, and resonance. Legitimacy refers to the quality of the EU rules, the rule-making process, and the process of rule transfer. In this perspective, the legitimacy of EU rules and, as a result, the likelihood of rule adoption, increase if rules are formal, member states are subject to them as well, the process of rule transfer fulfils basic standards of deliberation, and EU rules are shared by other international organizations. As for identity, the likelihood of rule adoption is expected to increase with the identification of the target state and society with the EU community. Finally, rule adoption will be facilitated if conflicting domestic rules are absent or delegitimated and if EU rules tie in with existing or traditional domestic rules (resonance).

\section{The lesson-drawing model}

According to the lesson-drawing model, non-member states adopt EU rules without EU incentives or persuasion. Lesson-drawing is a response to domestic dissatisfaction with the status quo (Rose 1991: 10-12). Policy-makers review policies and rules in operation elsewhere and make a prospective evaluation of their transferability, i.e. whether they could also operate effectively in the domestic context (Rose 1991: 23-4). The most general proposition of the lesson-drawing model is: a state adopts EU rule, if it expects these rules to solve domestic policy problems effectively.

Whether a state draws lessons from EU rules depends on the following conditions: a state has to( i) start searching for rules abroad; (ii) direct its search at the political system of the EU (and/or its member states); (iii) evaluate EU rules as suitable for domestic circumstances. These conditions depend in turn on four sets of factors: policy dissatisfaction; EU-centred epistemic communities; rule transferability; and veto players.

\section{EMPIRICAL FINDINGS: CONTEXTS OF CONDITIONALITY AND THE SUCCESS OF RULE TRANSFER}

In order to assess the effectiveness of the different modes of rule transfer, we draw on comparative cases studies covering a wide variety of CEECs and issueareas that were part of a collaborative research project on the Europeanization of Central and Eastern Europe (Schimmelfennig and Sedelmeier, forthcoming). In sum, these case studies suggest, first, that the external incentives model explains the broad patterns of successful rule transfer to the candidate countries well. Second, effective rule transfer is context-dependent: depending on the context of conditionality, the relevance of conditions highlighted by the external incentives model varies.

We distinguish two main contexts of EU external governance in Central 
Europe according to two broad issue-areas in which the activities of the EU also differ. Democratic conditionality concerns the fundamental political principles of the EU, the norms of human rights and liberal democracy. This context of conditionality started from the early days of the post-communist transformations in Central and Eastern Europe. The main external incentive in this context is, first, the establishment of institutional ties, such as association, and subsequently, the opening of accession negotiations. Once accession negotiations start, democratic conditionality recedes in the background, although the Commission still continues to monitor conditionality and the threat to break off negotiations remains in principle.

Acquis conditionality concerns the specific rules of the acquis communautaire. This context starts with concrete preparations for membership, which is the major external incentive for rule transfer. However, in the case of the CEECs, the EU has made far-reaching pre-accession alignment a condition even for starting accession negotiations. Thus, acquis conditionality started with the first programmes for regulatory alignment with the internal market, such as the Commission's 1995 White Paper, and became most pronounced with the beginning of accession negotiations in 1998 and 2000 respectively.

\section{Democratic conditionality}

In the context of democratic conditionality, the effectiveness of EU external governance depends crucially on the initial conditions in the candidate countries. Effective external governance was restricted to a particular set of countries, namely the more fragile and unstable democracies. By contrast, in the democratic frontrunners, such as the Czech Republic, Hungary and Poland, EU governance was unnecessary for democratization and democratic consolidation, while it was ineffective in undemocratic countries. In conformity with the external incentives model of external governance, these differences can be mainly explained by the costs that incumbent governments incur if they adopt EU rules (Schimmelfennig et al., forthcoming; Vachudova 2003).

The effect of democratic conditionality on the democratic front-runners of the region was rather small. They had already been well on the way towards democratic consolidation when the EU's policy of democratic conditionality was fully developed and would most probably have continued on this path even in the absence of EU conditionality. Either liberal democracy was a domestic equilibrium, or adoption costs were minor. In these countries, above all the two Baltic states of Estonia and Latvia, the most tangible effect of EU democratic conditionality was that on minority rights and protection (see Schimmelfennig et al., forthcoming; cf. Kelley 2004). Although the legitimacy of this aspect of democratic conditionality was doubtful to many observers, as the EU moved beyond the acquis and what its own members would accept on their own territory, in terms of output, the EU made a real difference in the CEECs by linking accession to the introduction of minority rights.

By contrast, where strongly nationalist and authoritarian governments were 


\section{Journal of European Public Policy}

in power, the domestic political costs of complying with EU conditionality proved prohibitively high. Democratic rules would have required these governments to give up the very instruments on which their political power rested. In cases such as Slovakia under the Mečiar government, Romania in the first half of the 1990s, Croatia during the Tudjman regime, Serbia under Milošević, or the European successor states of the Soviet Union (except for the Baltic countries), democratic conditionality was not sufficient for successful rule transfer. Rather, successful rule transfer required prior political change at the level of governments that brought democratic, reform-oriented political forces into power.

As Vachudova (2003) argues, however, EU incentives may still have been a sufficient condition for successful rule transfer, by producing such electoral change through domestic empowerment. Even if EU incentives failed to affect authoritarian governments directly, (the threat of) exclusion by the EU signalled to the societies in these states that the incumbent government was the main obstacle to their country's EU accession. These signals undermined the authoritarian governments' credentials as reformers, mobilized the electorate against the authoritarian governments, and induced a weak and fragmented opposition to join forces. In many cases, these changes brought reform-oriented parties to power - such as in the Balkans and in Slovakia between 1997 and 2000 - and put the countries (back) on the track to membership.

Whatever the causal role of EU conditionality in the electoral defeat of authoritarian parties, once reform-minded governments with lower domestic adjustment costs adopted rules conforming to EU democratic conditionality, the EU's conditionality appears to have been successful in locking-in democratic change, even if the former authoritarian parties subsequently returned to power, as they did in Romania and recently in Croatia. The EU supported the reformist governments by giving them a membership perspective or starting accession negotiations. Spurred by EU democratic conditionality, these governments then introduced so many changes and moved so far forward to EU membership that the costs of diverting from this path increased so much that even the former reform-adverse parties had to embrace the conditions of EU membership or see their election chances waning. To produce and sustain this change, however, the membership perspective had to be credible.

In sum, in the context of democratic conditionality, the success of EU external governance varied most importantly with the size of adoption costs. Given a credible membership perspective, it was the size of domestic political costs of incumbent governments that shaped their response to EU demands. By contrast, the determinacy of conditions and the size and speed of benefits did not have a systematic effect on rule adoption (Schimmelfennig et al., forthcoming). Whether democratic conditionality focused on the more determinate rules of democracy and general human rights, or on the less determinate minority rights, did not make a difference (see also Schwellnus, forthcoming). Authoritarian governments with high adoption costs also failed to comply 
when large benefits were close - as in the case of the Mečiar government in Slovakia.

A narrower set of conditions specified by the external incentives model thus explains the success and the limits of EU external governance in the context of democratic conditionality. While the alternative models may explain more readily why democratic reform and, to some extent, minority rights have been introduced without specific EU external incentives in the democratic frontrunner countries (see Schwellnus, forthcoming), the conditions that the alternative modes of external governance postulate seemed largely insignificant in the democratic laggards. The legitimacy of EU conditions that the social learning model specifies as a key condition for successful external governance appears causally irrelevant (Schwellnus, forthcoming; Schimmelfennig et al., forthcoming). Legitimate EU rules (democratic acquis rules shared and implemented by the member states) did not produce more compliance than the minority protection rules, which have remained outside the acquis and are not generally accepted by the member states. Nor does identity account for variation in rule adoption. Neither Croatian nor Turkish governments before the year 2000 complied with EU human rights demands despite a strong selfidentification as 'Western' or 'European'. Rule resonance may only explain which pathway of democratic conditionality is most suitable: in cases of high societal resonance, domestic empowerment is an option.

\section{Acquis conditionality}

\section{External incentives and credible conditions}

In the context of acquis conditionality, the impact of the EU's external governance has been particularly pervasive. Studies in this area show that the key condition for the success of EU rule transfer is whether the EU sets its rules as conditions for countries with a credible membership perspective. We do observe some rule adoption even before the EU's conditionality was spelled out, but it was patchy and selective. CEEC governments often adapted EU rules or mixed EU rules with other models. However, once a given-issue area became the subject of the EU's conditionality, rule adoption increased dramatically and became a consistent feature across countries and issue-areas.

The external incentives model of external governance thus appears highly successful in explaining rule transfer in this context. However, not all of the conditions that the model postulates as relevant are equally important. The credibility that the EU will reward rule adoption with membership, which increased significantly once accession negotiations started, emerges as the most important factor influencing the cost-benefit calculations of CEEC governments. The massive benefits of $\mathrm{EU}$ membership being within close reach, the fulfilment of EU acquis conditions became the highest priority in CEEC policy-making, crowding out alternative pathways and domestic obstacles. 


\section{Journal of European Public Policy}

The importance of adoption costs thus contrasts sharply from the context of democratic conditionality. As acquis conditionality does not concern the political system and bases of political power as such, governments generally do not have to fear that the costs of rule adoption in individual policy areas will lead to a loss of office. Costs are thus unlikely to be prohibitive. Moreover, once a credible membership perspective has been established, adoption costs in individual policy areas are discounted against the (aggregate) benefits of membership, rather than just the benefits in this particular policy area. Thus, adoption costs and domestic veto players do not play as decisive a role as in the case of democratic conditionality. For example, in the area of social policy, the CEECs even adopted the more costly rules relating to secondary legislation (such as health and safety at the workplace) more fully than the less costly rules relating to the social dialogue (Sissenich, forthcoming). Similarly, concerning the free movement of persons, rule adoption was more pronounced for the more costly Schengen rules than for the internal market rules (Grabbe, forthcoming).

In other cases, adoption costs explain variation in the speed of rule adoption across issue-areas and countries. In the Czech Republic, regionalization only increased after the reticent Klaus government had lost office (Brusis 2003; Jacoby, forthcoming). In Slovakia, rules for decentralization were eventually adopted after the election victory of the anti-Mečiar coalition, but the divergent preferences within the coalition that related to ethnic minority politics still made for protracted negotiations (Brusis 2003). In the area of environmental policy, opposition from the energy sector in Poland prevented the adoption of control-and-command instruments that the EU prescribed to combat air pollution. In contrast to the Czech Republic, EU rules were thus only adopted in the late 1990s once the EU's conditionality set in (Andonova, forthcoming). In sum, adoption costs and veto players may therefore influence the timing of rule transfer, but they do not lead to systematic variation in the success of EU rule transfer as such.

The stage of accession negotiations might have affected negatively the credibility of conditionality. For example, civil service reforms in the Czech Republic - a front-runner that might thus not have feared exclusion in the late stages of accession negotiations - were much less in line with the EU's requirements than in most countries further down the line of accession (Dimitrova, forthcoming). However, such a negative effect is not consistent. Towards the final stages of accession negotiations, rule adoption increased in particular in the more costly areas in which the CEECs had delayed it, such as the Schengen rules in Hungary and Poland (Grabbe forthcoming).

The salience that the EU attaches to a particular area, rather than the stage of accession negotiations as such, appears as a key factor that renders the EU's conditionality credible, and hence increases the success of rule transfer. CEEC governments know that the Commission and member states monitor adoption of these rules particularly closely and give them a higher weight in their enlargement decision. EU actors clearly communicated to the CEECs that the 
Schengen rules were a key condition for membership (Grabbe, forthcoming). By contrast, parts of the Commission and some member states indicated that rather superficial alignment would not present an obstacle to concluding negotiations in the areas of EU social policy (Sissenich, forthcoming) and to some extent (maybe paradoxically in view of the repeated emphasis on the need for institutional capacity) civil service reform (Dimitrova, forthcoming).

Thus, with regard to acquis conditionality, a credible membership perspective and the setting of rules as conditions for membership appear the most important conditions for successful rule transfer through the external incentives mode of EU external governance. Variation in the timing of rule transfer can be explained primarily with domestic veto players and the salience of an issuearea for accession.

\section{Alternative modes of external governance}

However, how can we explain the - albeit limited - alignment of the CEECs with the acquis that happened prior to the explicit formulation of the EU's conditionality, or in issue-areas in which EU conditionality is absent? The broader picture of merely patchy, selective and adaptive transfer in the absence of conditionality conforms well to the conditions specified in the external incentives model. Yet, although EU incentives become a sufficient condition for rule adoption and trump all alternative mechanisms once the EU provides a credible membership perspective and spells out its requirements, EU incentives are thus not a necessary condition for rule transfer. To the extent that rule transfer occurred at all in such cases, it happened through the alternative modes of external governance - social learning and lesson-drawing.

Examples of patchy rule adoption that predates the EU's conditionality include the adoption of command-and-control rules against air pollution in the Czech Republic - but not in Poland (Andonova, forthcoming); moves towards regionalization in Hungary, which started even before 1989, in contrast with the Czech Republic and Slovakia (Brusis 2003; Jacoby, forthcoming); central bank independence in Poland (Epstein, forthcoming); minority protection in Hungary and, to some extent, in Poland, but not in Romania (Schwellnus, forthcoming); or elements of health policies in Hungary and the Czech Republic that were oriented toward their pre-war Bismarckian health insurance systems (Jacoby, forthcoming).

In such cases of social learning and lesson-drawing, the presence or absence of epistemic communities promoting EU rules emerges as a key factor. The presence of EU-centred networks of experts and officials was an important condition, for example, for the import of EU rules for clear air policies in the

(2) Czech Republic, while the dominance of more US-centred IFI experts led to the adoption of different rules in Poland (Andonova, forthcoming). Dense interactions between CEEC officials and experts with EU counterparts also facilitated social learning, as in the case of Polish central banking (Epstein, forthcoming), or of officials in CEEC interior ministries who - in contrast to 


\section{Journal of European Public Policy}

their colleagues from foreign ministries or prime ministers' offices - appear to have largely internalized the ideas underpinning the EU's Schengen rules (Grabbe, forthcoming). At the same time, the presence of such epistemic communities alone is not a reliable indicator. For example, in contrast to earlier periods, consultations with EU health policy experts had little impact on Hungarian policies after 1998 (Jacoby, forthcoming).

A second area in which alternative modes of external governance appear relevant is the implementation of EU rules. Rules that are transferred through social learning or lesson-drawing are much less contested domestically. Implementation is more likely to result in behavioural rule adoption and sustained compliance, while external incentives primarily privilege formal rule adoption as the least costly form of rule adoption. Rachel Epstein (forthcoming) demonstrates that central banking independence in Poland, which was adopted as the result of a social learning process, enjoyed wide acceptance and was successfully defended against governmental attacks by a broad coalition of societal actors. By contrast, the coercive process that led to the adoption of agricultural policy resulted in widespread domestic resistance and contestation. Heather Grabbe (forthcoming) shows that social learning and lesson-drawing by officials in CEEC interior ministries led to a behavioural adoption of Schengen rules, despite the concerns of foreign ministries and prime ministers' offices. The importance of the external governance mode for implementation should become particularly important after the CEECs have become full members. Rule adoption motivated by external incentives and bargaining is more likely to cause domestic resistance and poor implementation in the absence of continued monitoring and threats of sanctions.

Finally, in cases in which the EU's requirements leave some room for choice within a larger universe of acceptable rules, the lesson-drawing model might explain which specific rules the CEECs adopt or how they interpret and use these rules. An example is regionalization in the Czech Republic and Slovakia. Both countries adopted a regionalization scheme compatible with EU rules. The Slovak government, however, designed regionalization to promote democratization, whereas the Czech government emphasized subsidiarity (Brusis 2003).

\section{EU GOVERNANCE IN THE CEECS: GOVERNANCE MODES AND EFFICIENCY}

\section{The dominance of 'old governance' in EU rule transfer}

The external incentives model thus stands out as the main mechanism through which the CEECs adopt EU rules. What does this tell us about the mode of EU governance in the CEECs? The literature on governance in the EU draws the most basic distinction is between 'old governance' and 'new' or 'network governance'. The former is characterized by hierarchical and vertical process of command, control, and steering by the state. The latter is based on 
horizontal co-ordination and co-operation, negotiated in decentralized settings between public and private actors (see e.g. Peters 2000). Whether there is indeed a distinctive 'EU mode of governance' is a contested issue. For example, Eising and Kohler-Koch claim that 'the central elements of the network mode of governance can be identified across a broad range of EC policy areas' (1999: 275). By contrast, Sbragia argues that 'the European Union exhibits a good deal of "old governance"' (2000: 221).

Drawing on this distinction, we can analyse external governance according to three key characteristics: (i) the significance of power relationships between the actors involved; (ii) the influence of the outsiders on the content and scope of rules transferred; and (iii) the types of actors involved in the process of rule transfer. On the basis of these features, EU governance through conditionality exhibits primarily characteristics associated with 'old governance' (see also Dimitrova 2002).

First, the relationship between EU actors and outsiders is highly asymmetrical. The EU draws heavily on its superior bargaining power to set and enforce its conditionality. It exercises a degree of power that it does not enjoy either vis-à-vis its own member states or vis-à-vis other external actors.

Second, the scope of the outsiders to influence the content of the rules that they import is severely limited. EU pre-accession conditionality starts from predetermined, non-negotiable formal rules decided by the member states alone. Even in accession negotiations, the scope for negotiations between the $\mathrm{EU}$ and the non-member countries is restricted to bargaining over transition periods. These transition periods merely relate to the speed of rule adoption. Negotiations thus do not involve the establishment of substantially new regulative rules. Rather, they serve as a forum for EU actors to explain the institutional rules to the representatives of the external states and to tell them what they have to do in order to adopt them.

Third, bureaucratic actors, intergovernmental or inter-bureaucratic relations, and a top-down process of rule transfer dominate the process of transferring these rules to the CEECs. The EU mainly relies on intergovernmental bargaining and privileges central governments and bureaucracies in the CEECs that it charges with implementing EU rules (Grabbe 2001). Even in social policy, where transnational networks were in place and societal actors should have played an important role (especially in the 'social dialogue'), they had no input (Sissenich 2002; forthcoming). Ironically, the role of transnational networks and domestic empowerment is greater in the context of democratic conditionality (Vachudova 2003), but is reduced once the candidate countries have achieved democratic consolidation.

\section{Effectiveness and limits of governance by conditionality}

Is EU governance in the CEECs effective? As we elaborated in the preceding section, the effectiveness of democratic conditionality is circumscribed by the domestic power costs of incumbent governments; while it might lock-in 


\section{Journal of European Public Policy}

democratic change in more fragile democracies, its ability to influence such changes is subject to debate. By contrast, the effectiveness of acquis conditionality appears impressive: the legislative adoption of the EU's acquis by the CEECs is an astonishing achievement. However, the question is whether short-term effectiveness was achieved at the expense of long-term inefficiency. In many policy areas, rule adoption consists primarily of formal transposition into national legislation, with implementation and effective enforcement in everyday policy-making lagging behind. What will happen after accession, when the external incentives underpinning EU conditionality will no longer be available? Will implementation and compliance slow down, stop or even be reversed? In light of our findings, there are reasons for concern.

First, in the absence of high conditional external benefits, domestic structures such as adoption costs, veto players, and resonance, which were superseded in the conditionality context, will gain causal impact again. This will be particularly relevant because rule adoption via external incentives is generally more likely to be contested than if it resulted from social learning or lesson-drawing. Second, many of the policy-makers or 'core executives' responsible for the quick transposition of EU rules and knowledgeable in EU affairs - and those with the most EU-friendly attitudes - will move to Brussels to assume the posts in the European organizations allotted to the new member states. Third, the new member states might not be willing to further accept the rules of the 'enlargement acquis', which were specifically designed for accession candidates but are not binding on full members. Moreover, as we know from British and Spanish experiences, accession deals that are considered unfair impositions lead to disgruntled newcomers who spend much of their early accession years trying to renegotiate perceived wrongs. Under all these circumstances, the short-term effectiveness of rule transposition in the context of conditionality might well be compromised by medium-term ineffectiveness of implementation.

In addition, acquis conditionality might compromise the beneficial effects of democratic conditionality by weakening the democratic process in the CEECs. Electoral choice and party competition on socio-economic issues were undercut by the fact that whoever was in government had to work towards adopting EU rules (Innes 2002). Parliamentary activity was to a large extent determined by the schedule of the accession process and the need to formally transpose EU legislation. In addition, acquis conditionality resulted in a mushrooming of regulatory agencies in the candidate countries, installing a technocratic regulatory state on top of the democratic institutions in place (Maniokas 2002). In sum, the EU might have the same ambivalent impact on democracy as in some of the older member states, which have emerged from a non-democratic past: firmly anchoring democratic institutions at the national level while undermining them at the supranational level.

Addresses for correspondence: Frank Schimmelfennig, Mannheim Centre for European Social Research, University of Mannheim, D-68131 Mannheim, Germany. email: frank.schimmelfennig@mzes.uni-mannheim.de/Ulrich Sedel- 
meier, Department of International Relations and European Studies, Central European University, Nador utca 9, H-1051 Budapest, Hungary. email: sedel@ceu.hu

\section{NOTES}

1 This paper draws on the Introduction and the Conclusions of Schimmelfennig and Sedelmeier (forthcoming). The book is the product of two workshops, one at the ECPR Joint Sessions in Turin in June 2002, the other at the Robert Schuman Centre of the European University Institute in July 2003. We would like to thank the participants for their feedback and gratefully acknowledge financial support by the Volkswagen Foundation, the Robert Schuman Centre, and the Mannheim Centre for European Social Research.

2 On bargaining in EU negotiations in general, see Moravcsik (1998: 50-67) and in EU negotiations with accession countries in particular, see Moravcsik and Vachudova (2003).

3 For discussions of 'determinacy' or 'specificity' of rules and norms, see Franck (1990: 52-83) or Legro (1997: 34). For an explication of the concept of 'legalization', see Abbott et al. (2000). Jacoby and Cernoch (2002: 320) distinguish between high and low 'density of norms' as an important factor shaping the impact of the EU in Central and Eastern Europe. Dimitrova (2002) and Grabbe (2001: 1025) see the lack of rule clarity as one main inhibiting factor in the enlargement governance.

4 Here, and for the following hypotheses, the ceteris paribus clause applies.

5 As Tsebelis points out, however, the number of veto players alone is not an accurate predictor of policy stability. A new veto player does not affect policy stability if it is located within the unanimity core of the existing set of veto players, or if a political system with a higher number of veto players is ideologically less heterogeneous than one with fewer veto players (2002: 28-31).

\section{REFERENCES}

Abbott, K., Keohane, R., Moravcsik, A., Slaughter, A. and Snidal, D. (2000) 'The concept of legalization', International Organization 54(3): 401-19.

Andonova, L. (forthcoming) 'The Europeanization of environmental policy in Central and Eastern Europe', in Schimmelfennig and Sedelmeier (forthcoming).

Baldwin, R., Francois, J. and Portes, R. (1997) 'The costs and benefits of bastern bnlargement: the impact on the EU and Central Europe', Economic Policy 24: 125-76.

Börzel, T. and Risse, T. (2000) 'When Europe hits home: Europeanization and domestic change', European Integration Online Papers 4(15), available at < http:// eiop.or.at/eiop/texte/2000-015a.htm >

Brusis, M. (2003) 'Regionalization in the Czech Republic and Slovakia', manuscript.

Checkel, J. (2000) 'Compliance and conditionality', ARENA Working Papers 00/18, Oslo: ARENA.

Checkel, J. (2001) 'Why comply? Social learning and European identity change', International Organization 55(3): 553-88.

Dimitrova, A. (2002) 'Enlargement, institution-building and the EU's administrative capacity requirement' West European Politics 25(4): 171-90.

Dimitrova, A. (forthcoming) 'Europeanization and administrative reform in Central and Eastern Europe', in Schimmelfennig and Sedelmeier (forthcoming). 


\section{Journal of European Public Policy}

Eising, R. and Kohler-Koch, B. (1999) 'Governance in the European Union. A comparative assessment', in B. Kohler-Koch and R. Eising (eds), The Transformation of Governance in the European Union, London: Routledge, pp. 267-85.

Epstein, R. (forthcoming) 'Rule adoption in post-communist Poland: central banking and agriculture', in Schimmelfennig and Sedelmeier (forthcoming).

Franck, T. (1990) The Power of Legitimacy among Nations, New York: Oxford University Press.

Friis, L. and Murphy, A. (1999) 'The European Union and Central and Eastern Europe: governance and boundaries', Journal of Common Market Studies 37(2): 211-32.

Grabbe, H. (2001) 'How does Europeanization affect CEE governance? Conditionality, diffusion and diversity', Journal of European Public Policy 8(6): 1013-31.

Grabbe, H. (forthcoming) 'The Europeanization of movement of people', in Schimmelfennig and Sedelmeier (forthcoming).

Innes, A. (2002) 'Party competition in postcommunist Europe. The great electoral lottery', Comparative Politics 35(1): 85-104.

Jacoby, W. and Cernoch, P. (2002) 'The pivotal EU role in the creation of Czech regional policy', in R. Linden (ed.), Norms and Nannies. The Impact of International Organizations on the Central and East European States, Lanham, MD: Rowman \& Littlefield, pp. 317-39.

Jacoby, W. (forthcoming) 'Rule adoption in health and regional policy', in Schimmelfennig and Sedelmeier (forthcoming).

Kahler, M. (1992) 'External influence, conditionality, and the politics of adjustment', in S. Haggard and R. Kaufman (eds), The Politics of Economic Adjustment, Princeton: Princeton University Press, pp. 89-133.

Kelley, J. (2004) Ethnic Politics in Europe: The Power of Norms and Incentives, Princeton: Princeton University Press.

Killick, T. (1996) 'Principals, agents and the limits of BWI conditionality', The World Economy 19: 211-29.

Knill, C. and Lehmkuhl, D. (1999) 'How Europe matters. Different mechanisms of Europeanization', European Integration Online Papers 3(7), available at <http:// eiop.or.at/eiop/texte/1999-007a.htm >

Kohler-Koch, B. and Eising, R. (eds) (1999) The Transformation of Governance in the European Union, London: Routledge.

Legro, J. (1997) 'Which norms matter? Revisiting the "failure" of internationalism', International Organization 51(1): 31-64.

Maniokas, K. (2002) 'EU enlargement and Europeanization: when a patchwork becomes a blueprint. summary', manuscript.

March, J. and Olsen, J. (1989) Rediscovering Institutions. The Organizational Basis of Politics, New York: Free Press.

Moravcsik, A. (1998) The Choice for Europe. Social Purpose and State Power from Messina to Maastricht, London: UCL Press.

Moravcsik, A. and Vachudova, M. (2003) 'National interests, state power and EU enlargement', East European Politics and Societies 17(1): 42-57.

Peters, G. (2000) 'Governance and comparative politics', in J. Pierre (ed.), Debating Governance, Oxford: Oxford University Press, pp. 36-53.

Rose, R. (1991) 'What is lesson-drawing?', Journal of Public Policy 11(1): 3-30.

Sbragia, A. (2000) 'The European Union as coxswain: governance by steering', in J. Pierre (ed.), Debating Governance, Oxford: Oxford University Press, pp. 219-40.

Schimmelfennig, F. (2003) The EU, NATO and the Integration of Europe. Rules and Rhetoric, Cambridge: Cambridge University Press.

Schimmelfennig, F. and Sedelmeier, U. (eds) (forthcoming) The Europeanization of Central and Eastern Europe, Ithaca: Cornell University Press.

Schimmelfennig, F., Engert, S. and Knobel, H. (2003) 'Costs, commitments, and 
F. Schimmelfennig \& U. Sedelmeier: Governance by conditionality 687

compliance. The impact of EU democratic conditionality on Latvia, Slovakia, and Turkey', Journal of Common Market Studies 41(3): 495-517.

Schimmelfennig, F., Engert, S. and Knobel, H. (forthcoming) 'The Impact of EU Political Conditionality, in Schimmelfennig and Sedelmeier (forthcoming).

Schwellnus, G. (forthcoming) 'Non-discrimination and minority protection in the EU enlargement process', in Schimmelfennig and Sedelmeier (forthcoming).

Sissenich, B. (2002) 'The diffusion of EU social and employment legislation in Poland and Hungary', in R. Linden (ed.), Norms and Nannies. The Impact of International Organizations on the Central and East European States, Lanham, MD: Rowman \& Littlefield, pp. 287-315.

Sissenich, B. (forthcoming) 'The transfer of EU social policy to Poland and Hungary', in Schimmelfennig and Sedelmeier (forthcoming).

Smith, K. (2001) 'Western actors and the promotion of democracy', in J. Zielonka and A. Pravda (eds), Democratic Consolidation in Eastern Europe, Volume 2: International and Transnational Factors, Oxford: Oxford University Press, pp. 31-57.

Tsebelis, G. (2002) Veto Players. How Political Institutions Work. Princeton: Princeton University Press.

(3) Vachudova, M. (2001) 'The leverage of international institutions on democratizing states: Eastern Europe and the European Union', RSCAS Working Paper No. 2001/ 33, Florence: European University Institute.

Vachudova, M. (2003) 'EU leverage and the empowerment of domestic actors', manuscript.

Final version accepted for publication 19/4/04 